\title{
A educação permanente com profissionais da atenção primária à saúde: fomentando reflexões sobre a temática "Saúde Mental"
}

Marianna Karolina Pimenta Cota, Mariana Araújo Pena Bastos, Vanessa de Souza Amaral, Andréia Alves Reis, Adélia Contiliano Expedito, Deíse Moura de Oliveira

\section{Resumo}

A Estratégia Saúde da Família (ESF) figura como um cenário estratégico para trabalhar com pessoas em sofrimento psíquico, dada a proximidade e o vínculo passíveis de serem estabelecidos com famílias e comunidades. Um desafio importante para a saúde mental na ESF relaciona-se com as situações de adoecimento desencadeadas pela miséria e pelas ocorrências de violência enfrentadas no território, que impactam sobremaneira no processo saúde-doença da comunidade, desdobrando-se em dificuldades afetivas, emocionais e relacionais entre os seus membros. Objetivo: relatar a experiência de oficinas educativas sobre a temática "Saúde Mental" com profissionais que atuam na Atenção Primária à Saúde (APS) de Viçosa e região, participantes de um Projeto de Educação Permanente (PEP). Trata-se de um relato de experiência inscrita em um projeto de extensão universitária que se propõe trabalhar com Educação Permanente junto a profissionais da APS de Viçosa e municípios adjacentes. Tal experiência se deu no período de maio a julho de 2016, cuja temática saúde mental foi escolhida pelos participantes do PEP, em virtude dos desafios que vivenciam neste campo de atuação. Optou-se pelas oficinas educativas como estratégia metodológica, sendo realizadas três oficinas sobre o tema, perfazendo uma por mês. Num primeiro momento buscou-se entender quais eram as reais demandas trazidas pelos participantes em relação ao assunto. No segundo encontro, em virtude de um diagnóstico feito no primeiro, foi abordada a saúde mental dos próprios profissionais diante do contexto que atuam. No último encontro a atividade foi baseada em uma casuística envolvendo demandas de saúde mental a serem refletidas e respondidas pelos profissionais. Durante as oficinas evidenciou-se um despertar dos profissionais para a necessidade de reflexão e apropriação do tema e do seu próprio estado de saúde mental, partindo do pressuposto de que para prestar o cuidado há que se estar bem consigo mesmo. Foi unânime no grupo que o contexto em que atuam, perpassado por mazelas sociais e relações interpessoais tensionadas com a equipe fragilizam substancialmente a saúde mental dos trabalhadores da saúde. A discussão da casuística revelou que mesmo em regiões distintas os problemas são semelhantes, propiciando um despertar sobre como conduzir possíveis situações, bem como a identificação de como cada núcleo de saber profissional deve se implicar e enfrentar os desafios da saúde mental na APS. O presente relato reitera a importância da educação permanente em saúde para os profissionais que dela participam. Em virtude de trabalhar questões oriundas dos nós críticos relacionados à temática saúde mental vivenciados na prática profissional, as oficinas possibilitaram aos participantes refletirem criticamente sobre si mesmos, bem como sobre suas ações diante dos dilemas cotidianos relacionados ao tema discutido.

Descritores: Atenção Primária à Saúde; Saúde Mental; Educação Continuada. 